\title{
Inisiasi Pembentukan Bank Sampah di Jetis Tarubasan Karanganom Klaten
}

\author{
Nur Rahmawati ${ }^{*}$, Pujastuti S. Diah ${ }^{1}$ \\ 1. Program Studi Agribisnis, Fakultas pertanian, Universitas Muhammadiyah Yogyakarta, Jln Brawijaya Tamantirto, Kasihan Bantul, \\ Yogyakarta 55183 Telp. (0274) 387656 \\ Email: rahma_wati_mf@umy.ac.id \\ DOI: 10.18196/ppm.32.212
}

\begin{abstract}
Abstrak
Rendahnya pengetahuan dan kesadaran masyarakat tentang pengelolaan sampah serta anggapan bahwa sampah tidak mempunyai nilai ekonomi menjadi permasalahan utama di lingkungan PKK RW o3 Jetis. Kegiatan ini bertujuan untuk membangun kepedulian masyarakat terhadap sampah sehingga bermanfaat secara sosial, ekonomi, dan lingkungan. Inisiasi pembentukan bank sampah adalah upaya peningkatan pendapatan masyarakat. Metode yang dilakukan adalah Benchmarking, yakni pelatihan pemilahan sampah, diskusi dengan tokoh masyarakat, pelatihan pengelolaan bank sampah dan sosialisasi keberadaan bank sampah. Pelaksanaan kegiatan diawali dengan kunjungan ke bank sampah Jatidiri, dilanjutkan pelatihan pemilahan sampah. Kegiatan ini diikuti oleh calon pengelola sampah. Kegiatan selanjutnya adalah diskusi dengan tokoh masyarakat dan terbentuklah bank Sampah yang bernama Bank Sampah RESIK-an. Untuk membekali pengurus atau calon pengelola bank sampah, diadakan kegiatan pelatihan dan pengelolaan bank sampah dari tim Bank Sampah Semut Harjo Polanharjo. Sehubungan dengan adanya Covid-19, sosialisasi keberadaan bank sampah dilakukan dengan menyebarkan leaflet kepada masyarakat di wilayah RW o3 Jetis, Tarubasan, Karangnom, Klaten. Kesimpulan dari kegiatan ini adalah semua kegiatan yang dilakukan dengan berbagai metode berjalan lancar dan mendapat respons yang sangat baik dari mitra. Semangat dan keinginan untuk berubah menjadi modal awal demi kemajuan masyarakat dalam pengelolaan sampah.
\end{abstract}

Kata Kunci: Inisiasi, bank sampah, pengelolaan, sosialisasi

\section{Pendahuluan}

Indonesia termasuk ke dalam sepuluh besar negara dengan jumlah penduduk terbanyak di dunia. Hal ini tidak menutup kemungkinan menimbulkan sejumlah persoalan lanjutan, di antaranya adalah produksi sampah dan pembuangannya. Berdasarkan data Kementerian Lingkungan Hidup dan Kehutanan (KLHK), sampah di Indonesia pada tahun 2019 diperkirakan akan mencapai 64 juta ton (Fatah, 2019). Tidak dapat dipungkiri bahwa sampah yang tidak dikelola dengan baik akan menyebabkan pencemaran lingkungan.

Upaya yang dilakukan dalam mengatasi masalah lingkungan, terutama sampah, harus dimulai dari individu, dimulai dari yang kecil, dan dimulai dari sekarang dengan cara pembiasaan dalam keluarga dan ditularkan kepada masyarakat supaya terjadi perubahan. Pada umumnya, dalam rumah tangga, pengelolaan sampah belum dilakukan secara optimal. Masih dicampur pembuangannya untuk berbagai macam sampah. Sampah rumah tangga perlu dipisahkan antara sampah organic dan sampah anorganik. Sampah organik dapat dijadikan kompos, sedangkan sampah rumah tangga anargonik bisa didaur ulang dan dapat dijadikan bahan yang bernilai ekonomis (Jumar, Fitriyah, \& Kalalinggi, 2014). Sampah organik yang mudah diurai dibusukkan, sedangkan sampah anorganik, seperti plastik, aluminium foil, kaca, kaleng yang sulit dibusukkan, bahkan tidak bisa busuk, dibuang secara bersamaan. Padahal, sebenarnya sampah masih bisa didaur ulang dan dimanfaatkan lebih lanjut.Sampah yang didaur ulang akan bisa menambah pemasukan bagi rumah tangga dan mengurangi problem lingkungan sekitarnya. Oleh karena itu, perlu ada perubahan paradigma mengenai sampah perlu dilakukan secara berkelanjutan (Asteria \& Heruman, 2016). 
Dalam pengelolaan sampah, harus ada perubahan cara pandang di masyarakat terhadap sampah. Sampah jangan dianggap sebagai barang yang kotor atau barang buangan. Akan tetapi, sampah merupakan barang yang bisa dimanfaatkan. Berkaitan dengan pengelolaan sampah rumah tangga dan sampah sejenisnya, Peraturan Pemerintah No. 81 tahun 2012 menyatakan bahwa mengolah dan memanfaatkan sampah harus menjadi langkah nyata dalam mengelola sampah. Masyarakat harus meninggalkan cara lama yang hanya membuang sampah. Masyarakat perlu didik dan dibiasakan memilah, memilih, dan menghargai sampah sekaligus mengembangkan ekonomi kerakyatan melalui pengembangan bank sampah (Tallei dkk, 2013 dalam (Asteria \& Heruman, 2016)).

Konsep 3R (Reduce, Reuse dan Recycle) adalah sebuah metode baru dalam pengelolaan sampah. Penerapan konsep 3R ini menjadi salah satu solusi pengelolaan sampah, di samping mengolah sampah menjadi kompos atau memanfaatkan sampah menjadi sumber listrik (PLTSa; Pembangkit Listrik Tenaga Sampah) (Shentika, 2016). Menurut Kementerian Lingkungan Hidup, konsep bank sampah merupakan konsep mengumpulkan sampah kering, memilahnya dan mempunyai manajemen layaknya perbankan. Dalam hal ini, yang ditabung bukan uang, melainkan sampah. Warga yang menabung (menyerahkan sampah) juga disebut nasabah dan memiliki buku tabungan. Warga tersebut dapat meminjam uang yang nantinya dikembalikan dengan sampah yang seharga dengan uang yang dipinjam. Sampah yang ditabung akan ditimbang dan dihargai dengan sejumlah uang. Selanjutnya, sampah akan dijual di pabrik yang sudah bekerja sama dengan bank sampah (Anonim, 2012).

Dusun Jetis merupakan salah satu dusun di Desa Tarubasan, Kecamatan Karanganom, Kabupaten Klaten. Dusun Jetis hanya terdiri atas 1 RW, yaitu RW 03 yang terdiri atas 2 RT, yaitu RT 04 dan 05. Jumlah kepala keluarga yang ada di Dukuh Jetis sebanyak 105. Sebagian besar ibu kepala keluarga berperan sebagai ibu rumah tangga. Kegiatan yang ada di Dusun Jetis antara lain PKK, Pertemuan RW, Kegiatan Muda-Mudi, dan pengajian. Pengelolaan sampah di Dusun Jetis, Desa Tarubasan, Karanganom belum berjalan secara optimal. Permasalahan yang dihadapai adalah, terbatasnya pengetahuan dan rendahnya kesadaran masyarakat tentang pentingnya pengelolaan sampah rumah tangga. Masyarakat belum peduli terhadap pengelolaan sampah dan belum ada nilai ekonomis dari pengelolaan sampah. Selama ini, masyarakat masih menganggap sampah sebagai barang sisa yang tidak mempunyai nilai ekonomis.

\section{Metode Pelaksanaan}

Kegiatan ini dilaksanakan di Dusun Jetis, Tarubasan, Karanganom, Klaten dengan sasaran ibu-ibu kelompok PKK RW 03 yang terdiri atas RT 05 dan RT 06. Warga perempuan dapat menjadi agen perubahan dalam pengelolaan lingkungan di perkotaan, bahkan menjadi bagian dari penyelesaian konflik lingkungan di perkotaan (Asteria, 2013 dalam (Asteria \& Heruman, 2016)). Sehubungan dengan adanya pandemi Covid-19, sasaran atau calon pengelola bank sampah yang mengikuti benchmarking dibatasi hanya 10 orang, yaitu Ibu RT sebanyak 2 orang dan wakil dari masing-masing RT sebanyak 4 orang serta stakeholder.

Metode pelaksanaan yang dilakukan adalah 1) benchmarking ke pengelola bank sampah yang sudah berhasil 2) pendampingan pembentukan bank sampah 3) pelatihan pengelolaan bank sampah, dan 4) penyuluhan tentang edukasi pengelolaan sampah rumah tangga. 
Selain kegiatan penyuluhan, forum diskusi, pelatihan, dan pendampingan, sasaran atau mitra akan mendapatkan hibah perlengkapan untuk pengelolaan bank sampah, yakni timbangan gantung, kalkulator, buku tabungan nasabah, buku kas, masker, karunggoni bekas, dan lain lain.

\section{Hasil dan Pembahasan}

Kegiatan pengabdian masyarakat tentang inisiasi pembentukan bank sampah dilaksanakan mulai bulan Juni 2020. Ada perubahan metode pada beberapa kegiatan yang akibatkan adanya pandemi Covid-19. Pada mulanya, kegiatan ini diawali dengan penyuluhan kepada sasaran, yaitu pengurus anggota PKK RW03 Jetis, Tarubasan, Karanganom, Klaten saat pertemuan bulanan pada tanggal 6 Mei 2020. Namun, karena adanya pandemi Covid-19 yang tidak memperbolehkan adanya kerumunan masa, kegiatan ini ditunda dan dialihkan dengan metode lain, yaitu dengan membagikan leaflet pada rangkaian kegiatan akhir atau sosialisasi keberadaan bank sampah kepada masyarakat.

Kegiatan pengabdian masyarakat tentang inisiasi pembentukan bank sampah terdiri atas benchmarking ke pengelola bank sampah yang sudah berhasil, pendampingan pembentukan bank sampah, pelatihan pengelolaan bank sampah, dan penyuluhan tentang edukasi pengelolaan sampah rumah tangga.

\section{Benchmarking}

Benchmarking adalah kegiatan kunjungan ke bank sampah yang sudah berhasil. Kegiatan ini bertujuan untuk membuka wawasan bagi ibu-ibu pengurus dan anggota PKK RW 03 Jetis, Tarubasan, Karanganom, Klaten tentang cara pengelolaan bank sampah. Selain itu, kegiatan anjang sana ini juga merupakan ajang belajar bersama tentang cara mengelola bank sampah, mulai dari pemilahan sampah, administrasi pengelolaan bank sampah, dan administrasi keuangannya.

Benchmarking ini dilakukan pada tanggal 5 Juni 2020 di bank sampah yang sudah sukses, yakni Bank Sampah Jati Diri yang berlokasi di Wareng, Wangen, Polanharjo, Klaten yang berjarak $7 \mathrm{~km}$ dari lokasi mitra. Kegiatan ini diikuti oleh 12 orang yang terdiri atas 2 orang ibu pengurus RT dan perwakilan dari RT 05 dan 06 masing-masing 5 orang. Respons yang sangat positif dari mitra dapat dilihat dari niat, motivasi, dan semangatnya. Kegiatan ini diharapkan bisa mempercepat pembentukan bank sampah di lingkungan Dusun Jetis, Tarubasan, Karanganom, Klaten. Berikut foto kegiatan benchmarking.

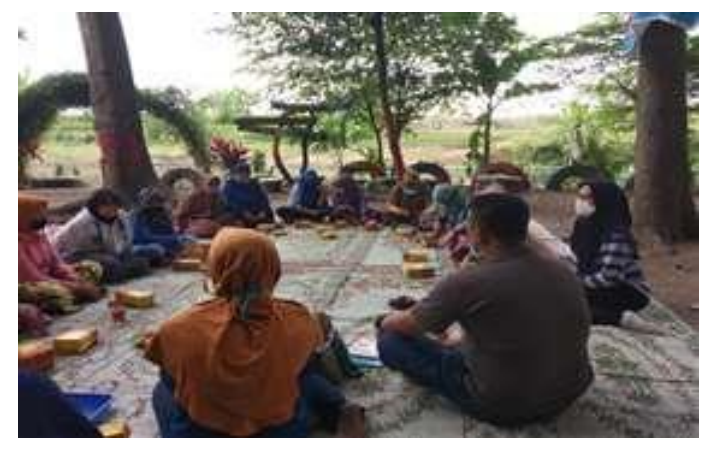

Gambar 1. Diskusi sistim pengelolaan bank Sampah

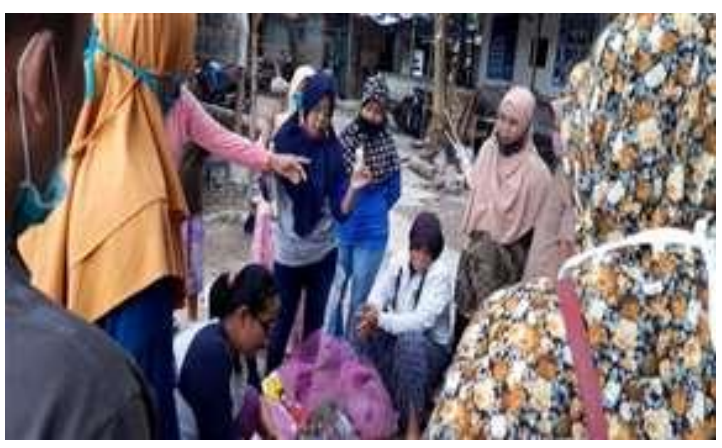

Gambar 2. Belajar

Memilah Sampah 
2. Pendampingan Pembentukan Bank Sampah

Pembentukan bank sampah merupakan salah satu tujuan dari kegiatan pengabdian masyarakat ini. Diperlukan pendampingan untuk dapat mewujudkan bank sampah di wilayah RW 03 Dusun Jetis, Tarubasan, Karanganom, Klaten. Kegiatan ini merupakan kelanjutan dari benchmarking di Bank Sampah Jati Diri. Pendampingan ini diawali dengan diskusi dan dialog antara tim pengabdian masyarakat dari UMY, wakil pengurus RW, RT, dan calon pengelola bank sampah. Diskusi dan dialog menghasilkan kesepakatan untuk membentuk bank sampah bernama RESIK-an dengan motto "Mengubah Masalah Menjadi Amanah dan Berkah" yang diketuai oleh Ibu Dwi Novarina. Tempat operasional bank sampah adalah di depan Balai RW Dusun Jetis, Tarubasan, Karanganom, Klaten.

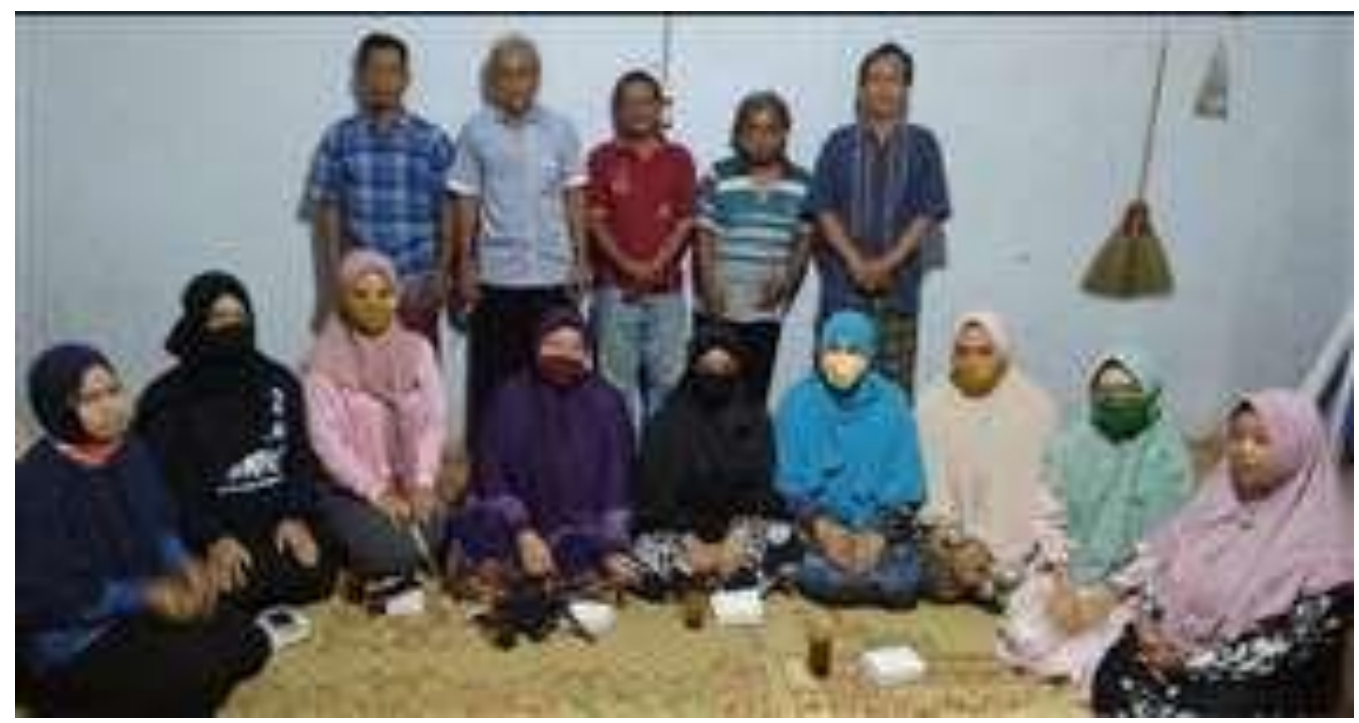

Gambar 3. Peserta Diskusi dan Dialog inisiasi Pembentukan Bank Sampah

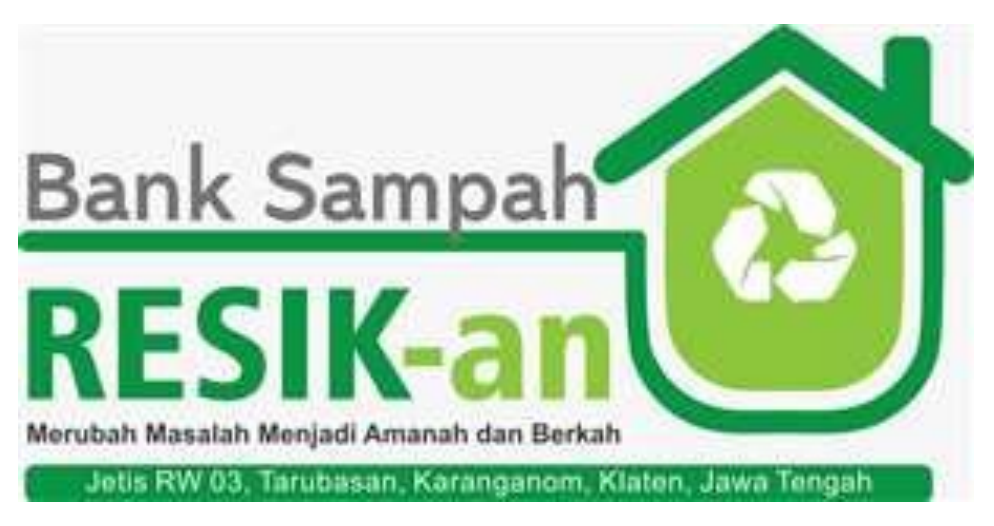

Gambar 4. Lambang Bank Sampah RESIK-an

\section{Pelatihan Pengelolaan Bank Sampah}

Kepengurusan bank sampah sudah terbentuk. Selanjutnya, diperlukan pelatihan tentang pengelolaan bank sampah bagi calon pengelola bank sampah. Materi pelatihan ini dimulai dari teknis pemilahan sampah, manajemen administrasi, dan manajemen keuangan. Pembicara tentang teknis pemilahan sampah rumah tangga diberikan oleh calon pengepul bank sampah yang akan menjadi mitra bank sampah RESIK-an. Materi yang diberikan mencakup 
pengelompokkan atau pemilahan sampah nonorganik berdasarkan jenisnya dan informasi harga sampah yang sudah dipilah. Pembicara tentang manajemen administrasi dan manajemen keuangan diberikan oleh tim Bank Sampah Semut Harjo, Polanharjo, Klaten. Materi yang diberikan dalam sistem administrasi mencakup pendaftaran, pembuatan akun nasabah, pencatatan pada buku besar, dan pencatatan pada buku tabungan. Sementara manajemen keuangan berisi tentang materi cara menentukan harga sampah pilah ke nasabah dan cara menghitung keuntungan bank sampah.

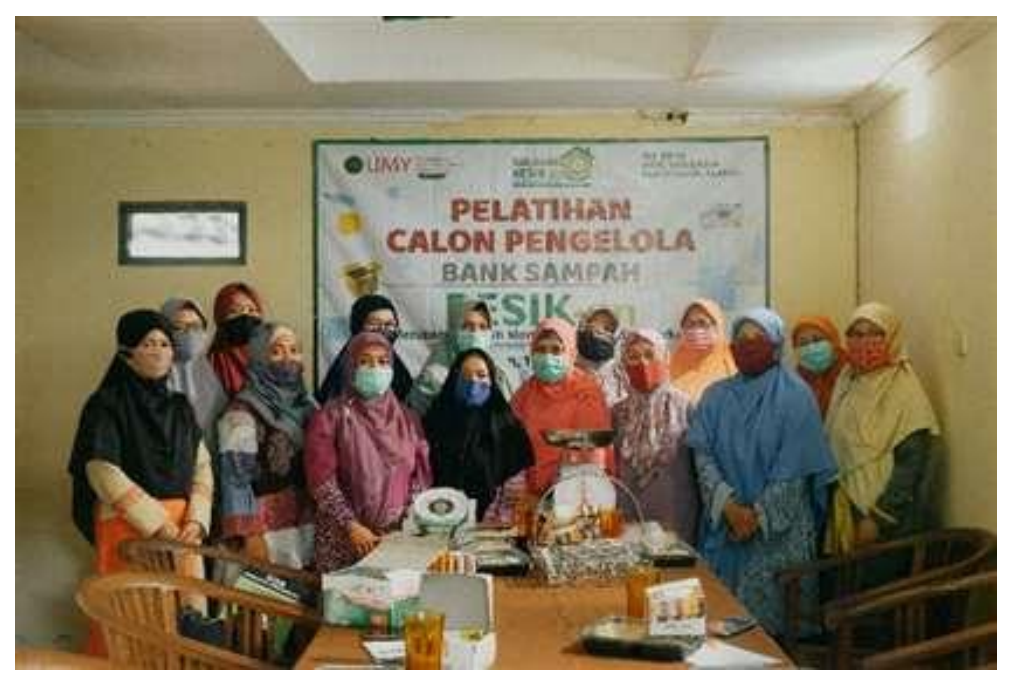

\section{Gambar 5. Peserta Pelatihan Calon Pengelola Bank Sampah RESIK-an}

Kegiatan pelatihan berjalan lancer. Peserta mengikuti semua agenda kegiatan dengan semangat. Setelah acara pelatihan, dilanjutkan dengan penyerahan barang yang dihibahkan untuk keberlanjutan program pemberdayaan ini. Barang yang dihibahkan terdiri atas timbangan kertas, timbangan pir/pegas, kantong untuk tempat sampah yang sudah dipilah, buku administrasi, buku notulen, dan buku tabungan. Penyerahan barang dilakukan oleh tim pengabdian masyarakat UMY kepada mitra sasaran (PKK RW 03) yang diwakili oleh ketua Bank Sampah RESIK-an, Ibu Dwi Novarina.

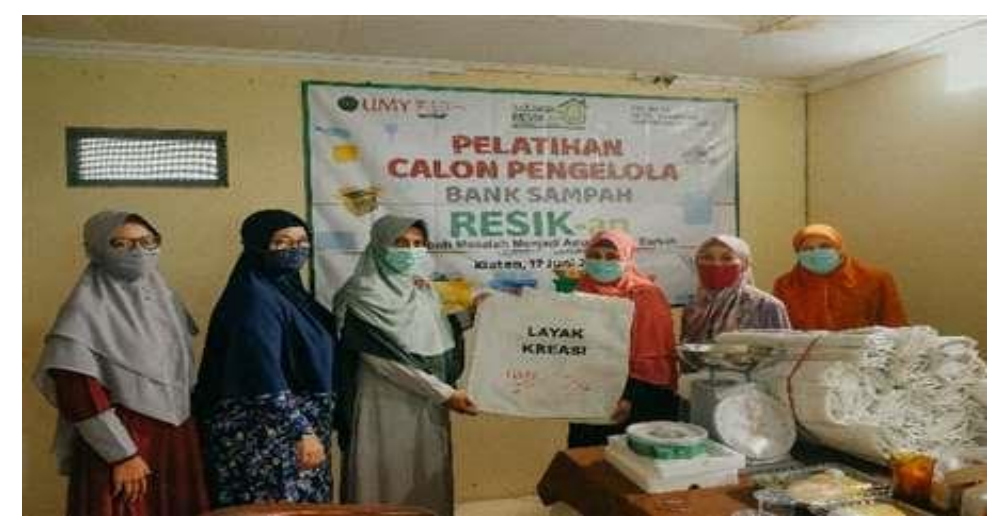

Gambar 6. Serah terima barang secara simbolis 

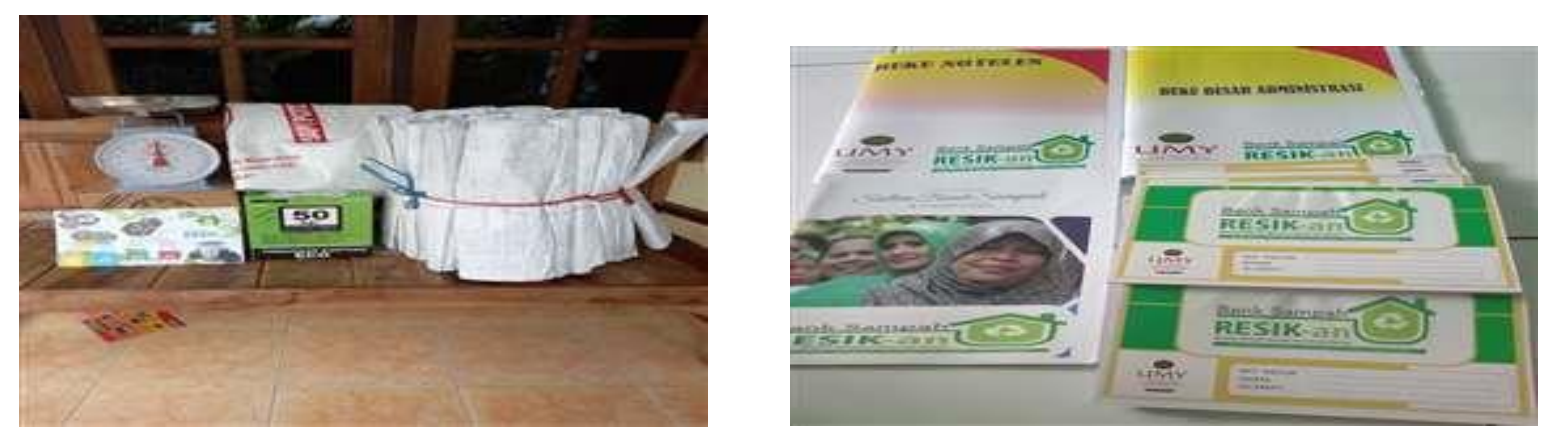

Gambar 7. Barang yang dihibahkan untuk keberlanjutan program
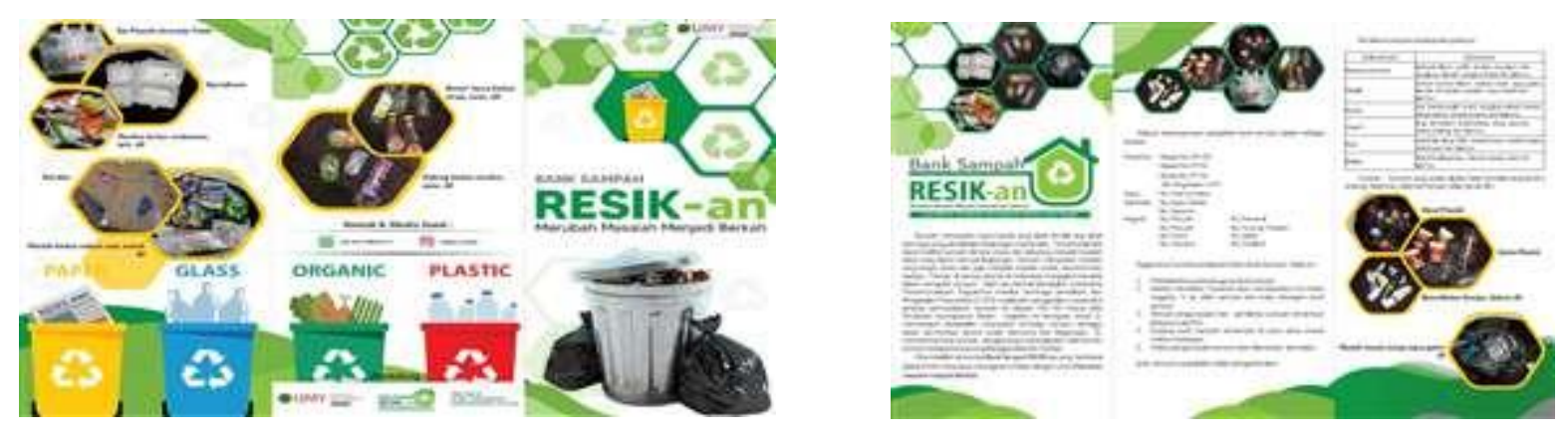

Gambar 8. Leaflet tentang Bank Sampah RESIK-an

\section{Sosialisasi Keberadaan Bank Sampah}

Keberadaan bank sampah di Dukuh Jetis, Tarubasan, Karanganom harus segera disosialisasikan kepada masyarakat, khususnya ibu-ibu anggota PKK RW 03. Sosialisasi ini bertujuan untuk memberikan pengenalan dan pengetahuan dasar mengenai bank sampah (Ajija, Muryani, \& Rusmita, 2020). Idealnya, sosialisasi keberadaan bank sampah ini melalui pertemuan rutin bulanan PKK RW 03. Namun, karena adanya pandemi Covid-19, bentuk sosialisasi kepada masyarakat diganti dengan menggunakan leaflet yang berisi tentang informasi keberadaan bank sampah, mulai latar belakang, kepengurusan, jenis barang yang dipilah, dan lain lain. Selain itu sosialisasi juga dilakukan melalui WhatsApp Grup PKK RW 03 Dusun Jetis, Tarubasan, Karanganom, Klaten. Masyarakat sangat senang karena bisa mengisi waktu luang untuk memilah sampah ditengah situasi pandemi Covid-19.

\section{Simpulan}

Kegiatan pemberdayaan masyarakat tentang inisiasi pembentukan bank sampah berjalan dengan lancer dan direspons positif oleh pengurus PKK RW 03 dan masyarakat di wilayah RW 03 Dusun Jetis, Tarubasan, Karanganom, Klaten walaupun dalam suasana pandemi Covid-19. Hasilnya terbentuk bank sampah bernama RESIK-an dengan motto "Merubah Masalah Menjadi Amanah dan Berkah". Semangat dan keinginan masyarakat untuk berubah telah menjadikan modal awal demi kemajuan masyarakat dalam pengelolaan sampah dan lingkungan. 


\section{Ucapan Terima Kasih}

Ucapan terima kasih kami ucapkan kepada LP3M UMY yang telah memberi dana pada kegiatan pengabdian ini melalui Program Kemitraan Masyarakat (PKM). Rasa terima kasih juga kami sampaikan kepada pengurus PKK RW03 Jetis, Tarubasan. Karanganom, Klaten yang telah memberi kesempatan kepada tim pengabdian masyarakat UMY untuk melaksanakan kegiatan pengabdian ini di wilayahnya.

\section{Daftar Pustaka}

Ajija, S. R., Muryani, M., \& Rusmita, S. A. (2020). Pendirian Bank Sampah pada Kelompok Ibu Rumah Tangga di Desa Jatitengah, Kecamatan Sugihwaras, Kabupaten Bojonegoro. Studi Kasus Inovasi Ekonomi, 4(1), 8-14. https://doi.org/10.22219/skie.v4i1.10076

Anonim. (2012). Profil Bank Sampah (p. 186). p. 186. Jakarta: Kementrian Lingkungan Hidup.

Asteria, D., \& Heruman, H. (2016). Bank Sampah Sebagai Alternatif Strategi Pengelolaan Sampah Berbasis Masyarakat di Tasikmalaya. Jurnal Manusia Dan Lingkungan, 23(1), 136. https://doi.org/10.22146/jml.18783

Fatah, D. (2019). Wow, Indonesia Produksi 64 Juta Ton Sampah per Tahun. Retrieved July 7, 2019, from https://indopos.co.id/read/2019/07/07/180601/wow-indonesia-produksi-64-jutaton-sampah-per-tahun/

Jumar, Fitriyah, N., \& Kalalinggi, R. (2014). Strategi Pengelolaan Sampah Rumah Tangga Di Kelurahan Lok Bahu Kecamatan Sungai Kunjang Kota Samarinda Jumar 1 , Nur Fitriyah 2 , Rita Kalalinggi 3. Jurnal Administrative Reform, 2(1), 101-112.

Shentika, P. A. (2016). Pengelolaan Bank Sampah di Kota Probolinggo. Jurnal Ekonomi Dan Ekonomi Studi Pembangunan, 8(1), 92-100. https://doi.org/10.17977/um002v8i12016p092 